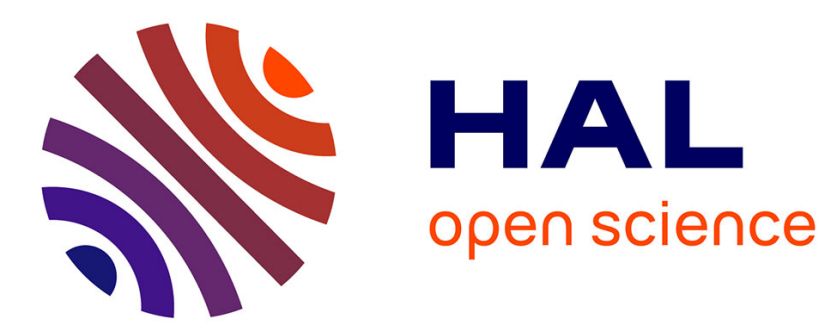

\title{
A common Greenlandic Inuit RING domain founder mutation
}

Thomas V. O. Hansen, Bent Ejlertsen, Anders Albrechtsen, Eva Bergsten, Peter Bjerregaard, Torben Hansen, Torben Myrhøj, Peter B. Nielsen, Vera Timmermans-Wielenga, Mette K. Andersen, et al.

\section{To cite this version:}

Thomas V. O. Hansen, Bent Ejlertsen, Anders Albrechtsen, Eva Bergsten, Peter Bjerregaard, et al.. A common Greenlandic Inuit RING domain founder mutation. Breast Cancer Research and Treatment, 2008, 115 (1), pp.69-76. 10.1007/s10549-008-0060-z . hal-00478231

\section{HAL Id: hal-00478231 \\ https://hal.science/hal-00478231}

Submitted on 30 Apr 2010

HAL is a multi-disciplinary open access archive for the deposit and dissemination of scientific research documents, whether they are published or not. The documents may come from teaching and research institutions in France or abroad, or from public or private research centers.
L'archive ouverte pluridisciplinaire HAL, est destinée au dépôt et à la diffusion de documents scientifiques de niveau recherche, publiés ou non, émanant des établissements d'enseignement et de recherche français ou étrangers, des laboratoires publics ou privés. 


\title{
A common Greenlandic Inuit BRCA1 RING domain founder mutation
}

\author{
Thomas v. O. Hansen - Bent Ejlertsen · Anders Albrechtsen · Eva Bergsten · \\ Peter Bjerregaard - Torben Hansen - Torben Myrhøj • Peter B. Nielsen · \\ Vera Timmermans-Wielenga • Mette K. Andersen · Lars Jønson • \\ Finn C. Nielsen
}

Received: 8 May 2008/ Accepted: 9 May 2008/Published online: 26 May 2008

(C) Springer Science+Business Media, LLC. 2008

\begin{abstract}
Germ-line mutations in the tumour suppressor proteins $B R C A 1$ and $B R C A 2$ predispose to breast and ovarian cancer. We examined 32 breast and/or ovarian cancer patients from Greenland for mutations in BRCAl and $B R C A 2$. Whereas no mutations were identified in 19 families, 13 families exhibited a BRCAl exon 3 nucleotide $234 \mathrm{~T}>\mathrm{G}$ mutation, which has not previously been reported in the breast cancer information core (BIC) database. The mutation changes a conserved cysteine 39 to a glycine in the $\mathrm{Zn}^{2+}$ site II of the RING domain, which is essential for BRCA1 ubiquitin ligase activity. Eight of the families had members with ovarian cancer, suggesting that the RING domain may be an ovarian cancer hotspot. By SNP array analysis, we find that all 13 families share a $4.5 \mathrm{Mb}$ genomic fragment containing the BRCAl gene, showing that the mutation originates from a founder. Finally, analysis of 1152 Inuit, representing almost $\sim 2 \%$
\end{abstract}

Electronic supplementary material The online version of this article (doi:10.1007/s10549-008-0060-z) contains supplementary material, which is available to authorized users.

T. v. O. Hansen ( $\square)$ · P. B. Nielsen · L. Jønson · F. C. Nielsen Department of Clinical Biochemistry 4111, Rigshospitalet, Blegdamsvej 9, 2100 Copenhagen, Denmark

e-mail: tvoh@rh.dk

B. Ejlertsen · E. Bergsten

Department of Oncology, Rigshospitalet, Blegdamsvej 9,

2100 Copenhagen, Denmark

\section{A. Albrechtsen}

Department of Biostatistics, University of Copenhagen,

Øster Farimagsgade 5, 1014 Copenhagen, Denmark

\section{P. Bjerregaard}

National Institute of Public Health, Øster Farimagsgade 5,

1399 Copenhagen, Denmark of the total Greenlandic Inuit population, showed that the frequency of the mutation was $1.0 \%$. We conclude that the BRCAl nucleotide $234 \mathrm{~T}>\mathrm{G}$ is a common Greenlandic Inuit founder mutation. The relative high frequency in the general population, together with the ease of screening and possibility to reduce mortality in gene carriers, may warrant screening of the Greenlandic Inuit population. Provided screening is efficient, about 5\% of breast- and $13 \%$ of ovarian cancers, respectively, may be prevented.

Keywords BRCA1 - RING domain - Cys39Gly · SNP array · Greenland · Inuit · Founder mutation

\section{Introduction}

Breast cancer is the leading cancer among women. Loss of BRCA1 (MIM 113705) and BRCA2 (MIM 600185) tumour suppressor function predispose to hereditary breast and ovarian cancer, conferring a lifetime risk of approximately $80 \%$ for breast cancer and $20-50 \%$ for ovarian

T. Hansen

Steno Diabetes Center, Niels Steensens Vej 2, 2820 Gentofte,

Denmark

T. Myrhøj

Department of Surgery, Dronning Ingrids Hospital,

Postbox 3333, 3900 Nuuk, Greenland

V. Timmermans-Wielenga

Department of Pathology, Rigshospitalet, Blegdamsvej 9,

2100 Copenhagen, Denmark

M. K. Andersen

Department of Clinical Genetics, Juliane Marie Center,

Rigshospitalet, Blegdamsvej 9, 2100 Copenhagen, Denmark 
cancer in female carriers [1]. BRCA1 and BRCA2 are involved in a variety of cellular processes, including maintenance of genome stability [2,3], DNA repair via homologous recombination $[4,5]$, transcriptional regulation [6], cell cycle control [7], chromatin remodelling [8] and ubiquitinylation [9].

BRCA1 exhibit a conserved amino terminus containing a $\sim 110$ residue RING (Realy Interesting New Gene) domain [10] and a conserved acidic carboxyl terminus containing two $\sim 90$ residues BRCT (BRCA1 $C$-terminal) domains [11], which are involved in phosphor-protein interactions [12]. The RING domain is characterized by a conserved pattern of seven cysteines and one histidine residue forming two distinct $\mathrm{Zn}^{2+}$ binding sites, termed site I and II [13-15] (Fig. 1). The BRCA1 RING domain interacts with the RING domain of BARD1 in vivo $[16,17]$ and the two proteins co-localize in nuclear dots during S-phase of the cell cycle and in nuclear foci following DNA damage $[18,19]$. Moreover, loss of BARD1, reduces the stability of BRCA1 [20]. The complex is involved in ubiquitinylation [21-24] and recently the factors were shown to bind RAP80 via CDCC80 (Abraxas) and to target BRCA1 to ubiquitin structures at DNA damage sites [25-29]. Several BRCA1 ubiquitinylation targets have been identified, including histones, $\gamma$-tubulin, the RNA polymerase II subunit RPB1, CtIP, ERalpha and
RPB8 [21, 30-35], suggesting that BRCA1 dependent ubiquitinylation regulates many cellular activities. One of the most interesting targets is ERalpha, which could explain the tissue specific effects mediated by BRCAl mutations. Mutations in the $\mathrm{Zn}^{2+}$ binding loops of the RING domain are assumed to be cancer predisposing, since they disrupt the ubiquitin ligase activity of BRCA1 [36].

Here we report the identification of a common BRCAl nucleotide (nt) $234 \mathrm{~T}>\mathrm{G}$ founder mutation, that is present in about $1 \%$ of the Greenlandic Inuit population. The mutation changes the conserved cysteine 39 in the $\mathrm{Zn}^{2+}$ site II of the RING domain to a glycine. The high frequency of the mutation in the general population indicates that screening of the Greenlandic population may be beneficial.

\section{Patients and methods}

Patients

Following referral to oncogenetic counselling, patients from Greenlandic families with clustering of breast and/or ovarian cancer have since 1999 been offered BRCAl and $B R C A 2$ mutation screening according to the guidelines of the Danish Breast Cancer Cooperative Group (DBCG)
Fig. 1 (a) Primary structure of the BRCA1 RING domain in different species. The RING domain is underlined in blue and the conserved cysteines and histidines, that form the $\mathrm{Zn}^{2+}$ site I and site II are indicated in grey and pink, respectively. The position of the mutated cysteine 39 is indicated by the arrow. (b) Solution structure of the BRCA1/BARD1 RING-domain heterodimer. The BRCA1 subunit is shown in blue and the BARD1 subunit in green. The Cys 39, 61 and 64 and His 41 residues of the $\mathrm{Zn}^{2+}$ Site II in the RING domain, are shown in pink. Helices that flank the core RING motif of both BRCA1 and BARD1 form the dimerization interface. The illustration was generated with the $\mathrm{Cn} 3 \mathrm{D}$ vers. 4.1 software (NCBI, Molecular Modelling Data Base (MMDB)) and based on data from [15]

\section{A BRCA1 RING domain}

Homo sapiens: Rattus norvegicus: Mus musculus: Canis familiaris: Bos taurus: Gallus gallus: Xenopus laevis:

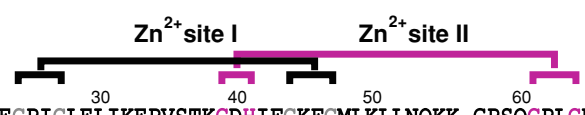

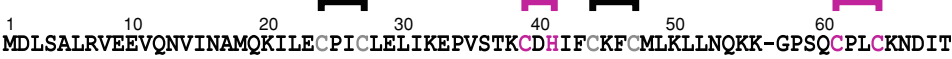
MDLSAVRIQEVQNVLHAMQKILECPICLELIKEPVSTQCDHIFCKFCMLKLLNQKK-GPSQCPLCKNEIT MDLSAVQIQEVQNVLHAMQKILECPICLELIKEPVSTKCDHIFCKFCMLKLLNQKK-GPSQCPLCKNEIT MDLSADRVEEVQNVLNAMQKILECPICLELIKEPVSTKCDHIFCKFCMLKLLNQRK-GPSQCPLCKNDIT MDLSADHVEEVQNVLNAMQKILECPICLELIKEPVSTKCDHIFCKFCMLKLLNQKK-GPSQCPLCKNDIT MDLSVIAIGDVQNVLSAMQKNLECPVCLDVIKEPVSTKCDHVFCRFCMFKLLSRKKKGVIQCPLCKTEVT MTCSRMDIEGICSVISVMQKNLECPICLELMKEPVATKCDHIFCKF CMLQLLSKKKKGTVPCPLCKTEVT Cys39 RING domain

\section{B Structure of the BRCA1-BARD1 heterodimer}

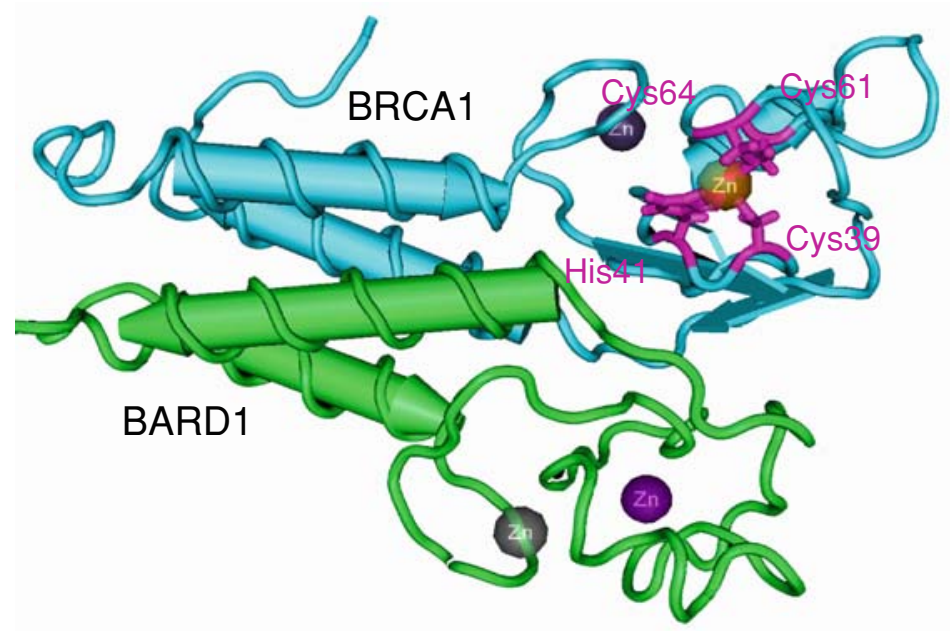


(www.dbcg.dk). Blood samples were obtained from breast and ovarian cancer patients after informed consent and the original consent encompassed additional screening in case of new methods or targets. The family history was verified using the registry of the DBCG, hospital medical records and pathology reports and genetic counselling was provided for every family member.

\section{BRCA1 and BRCA2 screening}

Genomic DNA was purified from whole blood using the QIAamp DNA mini kit (Qiagen), and paraffin embedded tumour tissue was purified using the Chemagic DNA tissue kit (Chemagen) according to the manufacturer's instructions. BRCA1 and BRCA2 were amplified using intronic primer pairs flanking each exon. PCR products were prescreened by dHPLC (denaturing high performance liquid chromatography) using the Wawe system (Transgenomic) and sequenced using an ABI3730 DNA analyzer (Applied Biosystems). Sequence variations were verified in a new blood sample. Moreover, genomic DNA was examined by MLPA analysis as recommended by the manufacturer (MRC-Holland). BRCA1 variants are numbered according to Genbank accession number U14680 in which the A in the AUG start codon has number 120, while the BRCA2 variants are numbered according to Genbank accession number NM_000059 in which the A in the AUG start codon has number 229. Furthermore, the guidelines from the Human Genetic Variation Society (www.hgvs.org/ mutnomen) were used.

\section{SNP chip analysis}

Genomic DNA was applied to $250 \mathrm{~K}$ StyI $(\sim 238.000$ SNPs) SNP-microarray chips and processed according to the manufacturer's instructions (Affymetrix). Briefly, $250 \mathrm{ng}$ of genomic DNA was digested with StyI and ligated to adapters. Adapter ligated DNA was amplified, purified, fragmented and labeled with biotin and hybridized to the arrays for $18 \mathrm{~h}$. The Affymetrix 450 fluidics station and the Affymetrix 3000 G7 gene scanner were used to wash, stain and scan the arrays. The CEL files were analysed using the BRLMM algorithm from Affymetrix Genotyping analysis software (GTYPE).

In order to assess whether the mutation happens once or several times, we investigate the local relatedness across the genome. The population allele frequencies for the Greenlandic population are difficult if not impossible to estimate because of the small population size, possible very large genomic variation between local communities (population stratification) and large variations in inbreeding coefficients. Because of the inbreeding, the problems obtaining an appropriate allele frequency and because of the linkage disequilibrium between SNPs, we could not use standard method for estimating relatedness. Instead we looked at the length of possible shared haplotype across the genotype. We defined a possible shared haplotype by a region where all individuals share at least one allele. Region with no markers i.e. centromeric regions and SNPs with missing data, were excluded.

Population samples

Blood samples were collected between 1999 and 2001 from Greenlanders with Greenlandic ethnicity (Inuit), defined as Greenlanders or mixed Greenlandic/Danish aged 18 and above living in three areas of West Greenland, including Nuuk, Qasigiannguit and four villages in the district of Uummannaq representing towns of varying size [37]. For all participants informed consent was obtained in writing and orally. The relevant ethical review committees approved the study. All together 1152 samples were analysed by TaqMan genotyping.

\section{Genotyping}

BRCAl nt $234 \mathrm{~T}>\mathrm{G}$ genotyping was performed using TaqMan assay (Applied Biosystems). The PCR reaction was performed as described by the manufacturer (Applied Biosystems). The BRCA1-234 primer and probe sequences were 5'-AGTCTGGAGTTGATCAAGGAACCT-3' (forward primer), 5'-GGAGCCACATAACACATTCAAACT T-3' (reverse primer), 5'-VIC-TCTCCACAAAGtGTGA CC-MGB-3' (probe 1) and 5'-6-FAM-TCCACAAAGg GTGACC-MGB-3' (probe 2). The allelic-specific fluorescence was measured using an ABI PRISM 7900HT Sequence Detector System (Applied Biosystems). Water control and previously genotyped samples were included in each plate to ensure accuracy of genotyping. Moreover all mutation positive samples as well as 35 random chosen wild-type samples were verified by sequencing.

\section{Results}

To identify disease-causing BRCA 1 and BRCA2 mutations in 32 breast and/or ovarian cancer patients form Greenland, the entire coding region and the exon-intron boundaries of BRCA1 and BRCA2, were examined by dHPLC and sequencing. Moreover, BRCA1 and BRCA2 were examined for large genomic rearrangements by MLPA analysis. Several known polymorphisms, as well as five unknown variants, including two undescribed intronic BRCA2 variations-IVS8-14delG and IVS24-8 C > T-were recognized (Supplementary Table 1). No disease causing mutations were identified in 19 of the families. The 
majority of these patients had weak or no family history of breast or ovarian cancer (Supplementary Table 2). In the remaining 13 families, in contrast, a BRCAl exon $3 \mathrm{nt} 234$ $\mathrm{T}>\mathrm{G}$ mutation was observed (Fig. 2), which has not previously been described in the breast cancer information core (BIC) database (www.research.nhgri.nih.gov/bic/). The mutation changes the conserved cysteine 39 in the $\mathrm{Zn}^{2+}$ site II of the RING domain to a glycine. The mutation was verified in a second blood sample, as well as in paraffin embedded breast cancer tumour tissue from one patient, where we also found that the corresponding wild-type allele was reduced in agreement with the two-hit model of carcinogenesis [38].

All families exhibiting the BRCAl nt $234 \mathrm{~T}>\mathrm{G}$ mutation had a history of breast and ovarian cancer (Table 1 and Supplementary Fig. 1). Mutation analysis was not possible in all affected members, due to lack of material or because the patients were deceased. The mutation was however present in all tested family members with breast and/or ovarian cancer, supporting that the

BRCA1 exon 3 - whole blood

C C T GTC TCCACAAA GT G T GAC CA CA TA T T T T GC
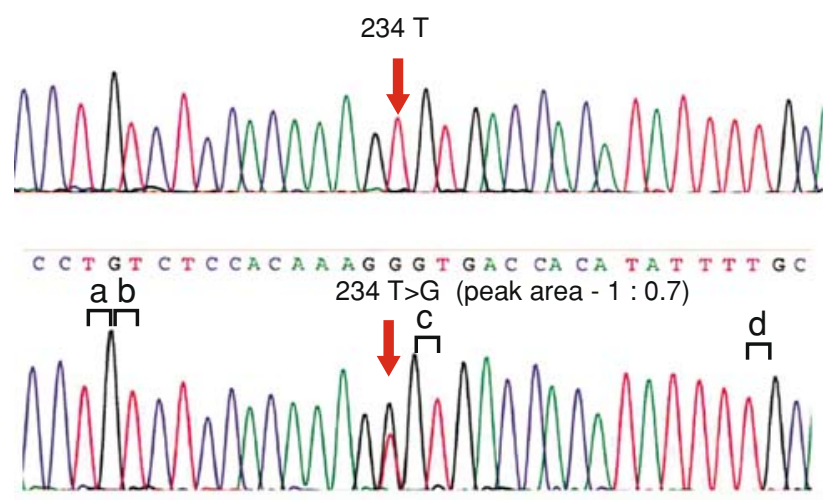

BRCA1 exon 3 - tumor

C C I G T C T C CACA A A G G T G A C CA CA T A T T T I G C $234 \mathrm{~T}>\mathrm{G}$ (peak area $-1: 0.3)$

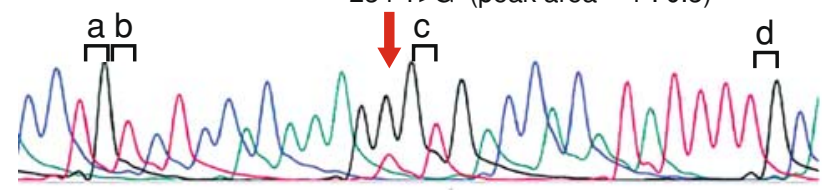

Fig. 2 Identification of the $B R C A 1 \mathrm{nt} 234 \mathrm{~T}>\mathrm{G}$ mutation. DNA was purified from blood and tumour samples from patients and BRCA1 exon 3 were amplified using intronic primer pairs flanking exon 3 and sequenced. DNA Sequences from blood (wild-type and mutation positive patient) and from tumour tissue are shown. The BRCAl nt 234 position is indicated by an arrow. The relative peak area for the nt $234 \mathrm{~T}$ and $\mathrm{G}$ from mutation positive blood and tumour samples were calculated to be approximately 1:0.7 and 1:0.3, suggesting loss of heterozygosity in the tumour tissue. To estimate the average peak variation, four GT dinucleotide pairs (a, b, c and d) from blood and tumour samples were compared and found to be 1:0.9 \pm 0.2 mutation co-segregates with breast and/or ovarian cancer in the families. All together eight family members aged between 33 and 49 years were tested positive in the absence of any tumours. The average age of onset for all female mutation positive probands was 41.8 years, ranging from 28 to 69 years, while the average onset for all mutation negative breast/ovarian cancer (and one fallopian tube cancer) patients was slightly higher (43.7 years, ranging from 28 to 68 years).

Since the mutation has not been reported in other populations and we did not previously encounter the mutation in Danish (Caucasian) breast and/or ovarian cancer patients, a SNP array analysis was performed to determine if the mutation represented an Inuit founder mutation. The Greenlandic individuals showed large variation in inbreeding, with an inbreeding coefficient ranging from no inbreeding $(F=0)$ to being extremely inbreed $(F=0.21)$. If the BRCAl mutation is a founder mutation, we would expect the carriers to share a common haplotype around the BRCAl gene. Fig. 3 shows the length of possible shared haplotypes between the 13 mutation carriers on chromosome 17. Around BRCAl, a $4.5 \mathrm{Mb}$ shared haplotype consisting of 274 SNPs was noted. None of the individuals without mutation shared this haplotype or any haplotype longer than $1 \mathrm{Mb}$ around the BRCAl gene. The shared haplotype between carriers is also the longest possible shared haplotype in the whole genome excluding centromeric regions without any SNPs (Supplementary Fig. 2). The possible shared haplotype with the second highest number of SNPs is $1.5 \mathrm{Mb}$ long located on the right side of the BRCAl gene on chromosome 17 and consists of 87 SNPs. Accordingly, we infer that the BRCAl nt $234 \mathrm{~T}>\mathrm{G}$ mutation is an Inuit founder mutation.

To estimate the frequency of the mutation in the Greenlandic Inuit population, we applied a simple and inexpensive TaqMan based BRCA1 nt $234 \mathrm{~T}>\mathrm{G}$ mutation analysis (Fig. 4). The assay also included known BRCAl nt $234 \mathrm{~T}>\mathrm{G}$ mutation carriers as well as 100 Danish negative controls. Totally, 1152 Greenlandic Inuit were analysed and 11 BRCA1 nt $234 \mathrm{~T}>\mathrm{G}$ mutation carriers corresponding to a population frequency of $\sim 1 \%$, were identified. The 11 mutation positive carriers included 7 females (aged 27, 27, 33, 36, 40, 56, 60 years, respectively) and 4 males (aged 31, 41, 50, 55 years, respectively). Their cancer status is currently unknown. All mutation positive carriers identified in this assay, as well as 35 random chosen wild-types were sequenced to verify the genotype.

\section{Discussion}

Despite Greenland is the world's largest island, the population is only $\sim 56.000$. About $88 \%$ of the population is of 
Table 1 Greenlandic families with the BRCA1 nt $234 \mathrm{~T}>\mathrm{G}$ mutation

\begin{tabular}{|c|c|c|c|c|}
\hline Family ID & Sex of proband & $\begin{array}{l}\text { Phenotype and age } \\
\text { at diagnosis }\end{array}$ & $\begin{array}{l}\text { Family history of breast and ovarian } \\
\text { cancers and age of diagnosis }\end{array}$ & $\begin{array}{l}\text { Family history of other } \\
\text { cancers }\end{array}$ \\
\hline 14829 & Female & BC 43 & M BC 49 & None \\
\hline 16142 & Female & BC 28 & S OC 31 & Unknown \\
\hline 21395 & Female & BC $38+41$ & M BC 47 & None \\
\hline 56387 & Female & ВС $43+49$, OC 55 & N OC 27 & Gyn? \\
\hline 58756 & Female & OC 69 & $\begin{array}{l}\text { S BC } 45, \text { D BC } 52, \text { PC OC } 57, \text { PC BC } 36, \\
\text { PC BC } 51, \text { PC BC } 49, \text { PCD, BC } 34\end{array}$ & Colon?, Rhinopharynx \\
\hline 60493 & Female & OC 33 & M BC 55 & None \\
\hline 60949 & Female & OC 45 & MC BC 50 PC BC $>50$ & Rectal, Colon \\
\hline 61273 & Female & BC 45 & S OC 50 & Abdominal \\
\hline 71572 & Female & OC 39 & M BC 40 & Unknown \\
\hline 72316 & Female & BC 39 & BC 45 & Rectal, Gyn, Lung \\
\hline 73428 & Female & BC 30 & M OC 40, MA OC & Gyn \\
\hline 73429 & Female & BC 39 & M BC 50 & None \\
\hline 73430 & Female & BC 52 & $\mathrm{~S} \mathrm{OC}, \mathrm{M} \mathrm{BC}$ & Thyroid \\
\hline
\end{tabular}

$\mathrm{BC}$-breast cancer, OC—ovarian cancer, Gyn—undefined gynecological cancer, $\mathrm{M}$-mother, S—sister, N-Niece, D—daughter, PC—paternal cousin, MA—maternal aunt, MC—-maternal cousin, PCD—paternal cousin's daughter

Fig. 3 SNP analysis of 13

Greenlandic Inuit families harbouring the BRCA1 nt 234 $\mathrm{T}>\mathrm{G}$ mutation. The lengths of the possible shared haplotypes are shown as lines in the top figure and the BRCAl gene is shown in green at position $38,449,840-38,530,994$. The bottom picture is the SNP density on chromosome 17
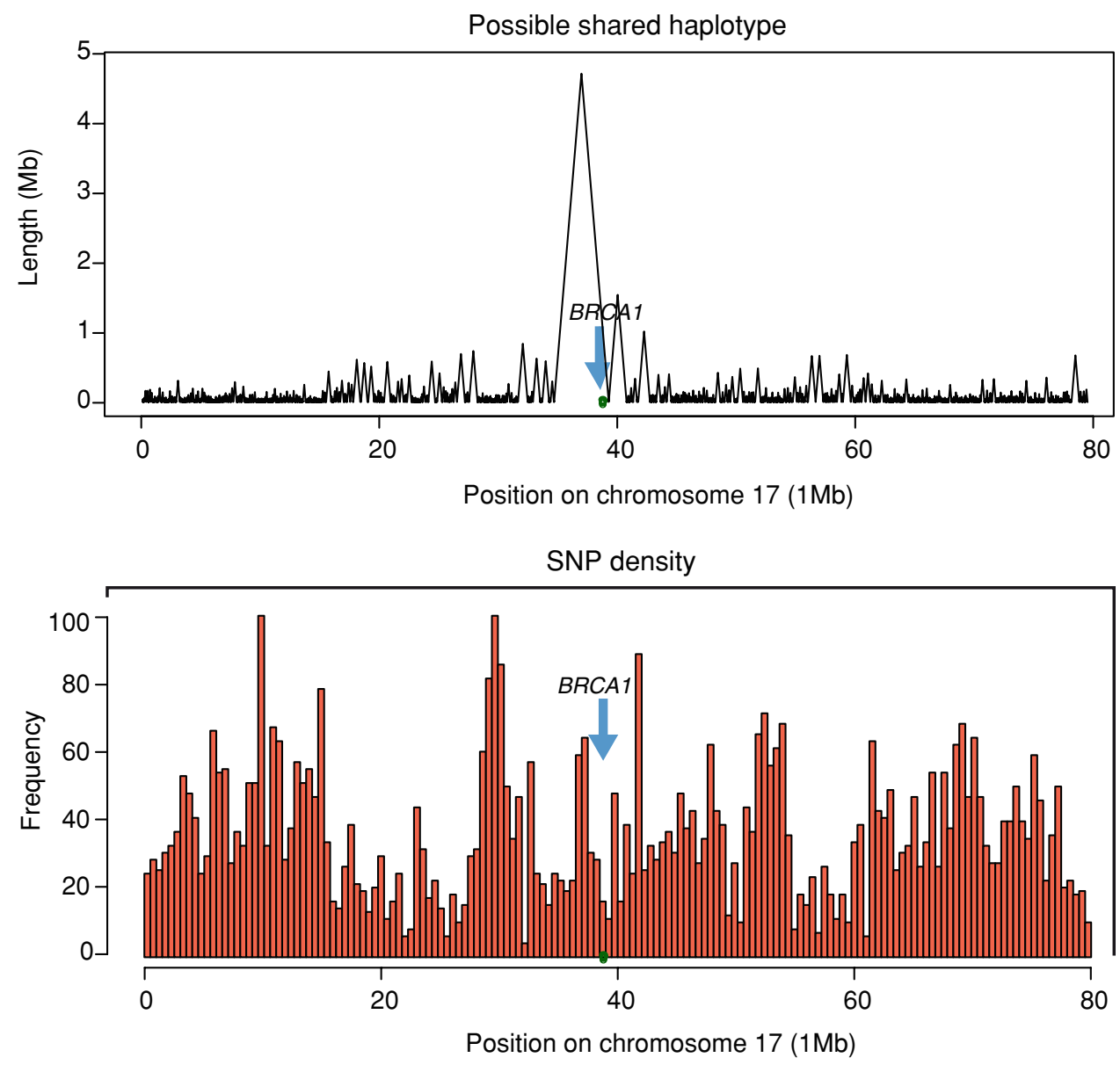

Inuit origin, many of which live in relatively isolated communities, under specialized polar conditions. Compared to the urbanized world, the population is relatively genetically homogenous, and the disease spectrum differs in many aspects from that found in other parts of the earth. Greenlandic Inuit exhibit a distinct pattern of cancer, 


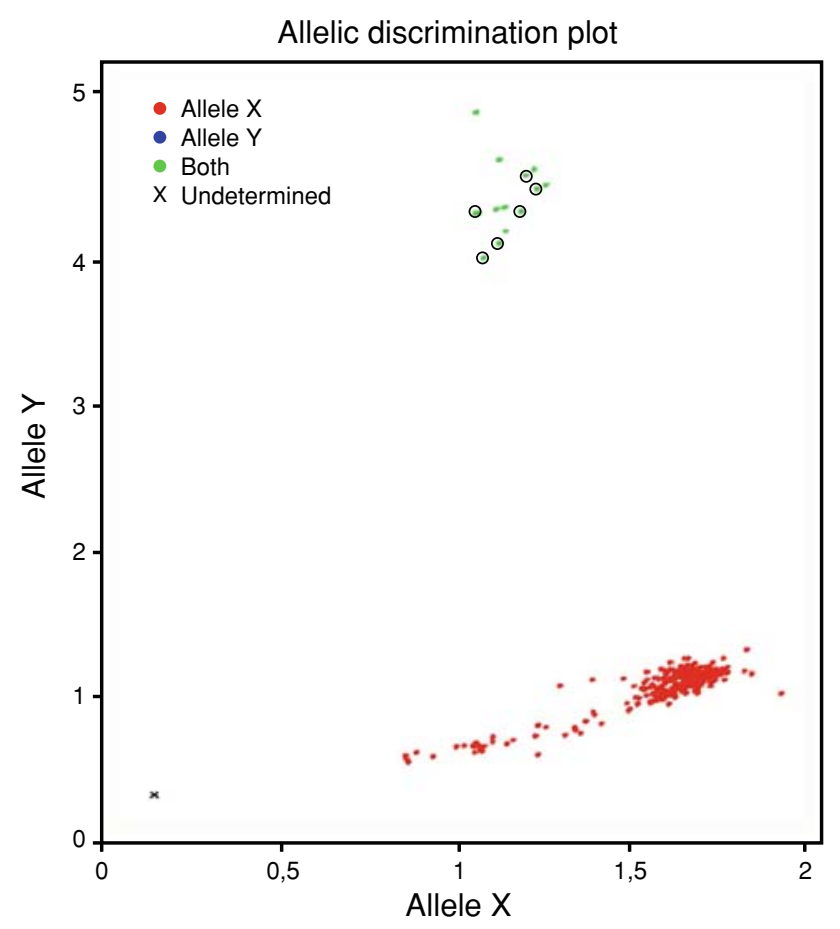

Fig. 4 Analysis of the frequency of the BRCA1 nt $234 \mathrm{~T}>\mathrm{G}$ mutation in the Greenlandic population. DNA from 1152 Greenlandic subjects were analysed by TaqMan genotyping. The Scatter diagram shows the end-point fluorescence detection from one 384-well plate using probes and primers detecting BRCA1 nt 234 position. $\mathrm{X}$ is a water control, the cluster of red dots represents nt $234 \mathrm{~T}$ subjects (wild-types), while the cluster of green dots represents subjects having the nt $234 \mathrm{~T}>\mathrm{G}$ mutation, and includes known mutation positive controls (circled)

characterized by a high frequency of e.g. Epstein-Barr Virus (EBV)-associated nasopharyngeal- and salivary gland carcinoma. Moreover Inuit exhibit a low frequency of tumours, that are common in Western countries, such as breast cancer, although the risk of breast cancer in Inuit women has increased markedly over the past 25-30 years [39].

During examination of breast and/or ovarian patients from Greenland for mutations in the BRCA1 and BRCA2 genes, we discovered a $B R C A 1$ nt $234 \mathrm{~T}>\mathrm{G}$ mutation in exon 3 (Cys39Gly) in 13 out of 32 families. Mutations substituting the conserved cysteine and histidine residues in the $\mathrm{Zn}^{2+}$ site I or site II of the BRCA1 RING domain have previously been reported as disease causing and are deleterious in functional and in silico assays [22, 24, 36, 40, 41]. Some mutations disrupt the ubiquitin ligase activity by interfering with the heterodimerization between BRCA1 and BARD1, while others change the ubiquitin ligase activity by disturbing the binding of E2 proteins like $\mathrm{UbcH} 5 \mathrm{c}$ to the BRCA1/BARD1 complex.

The 13 Greenlandic families with the BRCA1 nt 234 $\mathrm{T}>\mathrm{G}$ mutation all exhibited several members with breast and/or ovarian cancer. In the families where more family members were examined, the mutation co-segregated with the disease. In the mutation positive families several family members with the BRCAl nt $234 \mathrm{~T}>\mathrm{G}$ mutation did not have any signs of cancer (the oldest being 49 years). This is not surprising, considering that the penetrance of BRCAl mutations is not $100 \%$ and that the age of onset normally is variable [1]. In 8 out of the 13 families, there was both breast and ovarian cancer. We have also seen this in Danish families, carrying Cys44Ser and Cys61Gly RING domain mutations. Four families out of 4 with the Cys44Ser mutation and two out of 4 families with the Cys61Gly mutation exhibited ovarian cancer (unpublished data). Previous reports on the genotype-phenotype correlations in hereditary BRCAl breast and ovarian cancer, have indicated that mutations towards the $3^{\prime}$ end of the gene were associated with lower ovarian cancer risk [42, 43]. It was later proposed, that mutations in the central region of $B R C A l$ had a higher risk of ovarian cancer compared with the $C$ terminal and $\mathrm{N}$-terminal end of the gene, respectively [44]. Our findings may indicate, that mutations in the RING domain in the $N$-terminus of $B R C A l$ could predispose to ovarian cancer in the same way as mutations in the ovarian cancer cluster region (OCCR) of BRCA2 [45].

Founder mutations have previously been reported in $B R C A 1$ and BRCA2, including the Norwegian BRCA1 nt 1135 insA and nt 1675delA, the Swedish BRCA1 nt 3171ins5, the Icelandic BRCA2 nt 999del5, and the Ashkenazi Jews BRCA1 nt 185delAG mutations [46-49]. In the Inuit families, the 13 probands shared a possible $4.5 \mathrm{Mb}$ haplotype in the $B R C A l$ region, indicating that the mutation in the $B R C A l$ region happened once and segregated in the population to the 13 positive individuals as a founder mutation.

The frequency of the mutation in the Greenlandic population is close to $1.0 \%$. The analysis was performed on individuals from Nuuk, Qasigiannguit and four villages in the district of Uummannaq at the west coast where $95 \%$ of the Greenlandic population lives. Mutation positive carriers were identified in Nuuk and Qasigiannguit similar to some of the probands (Fig. 5). Moreover, three of the mutation positive probands were from Ittoqqortoormiit and three were from Tasiilaq, on the east coast. Thus the mutation is widespread in Greenland and it is possible that it originated 800-1000 years ago before the artic populations migrated into Greenland from Alaska [50]. Unfortunately, we did not have sufficient power to directly address the admixture among the probands. The population frequency is comparable to the population frequency found for the BRCA2 nt 999del5 founder mutation in the Icelandic population (0.6\%) [51] and for the BRCAl nt 185delAG founder mutation in Ashkenazi Jews $(\sim 1.0 \%)[52,53]$. Based on the population frequency about 280 Greenlandic Inuit women are estimated to carry the mutation. The employed TaqMan analysis has a high capacity per day and it is therefore useful for population screening. Due to the 


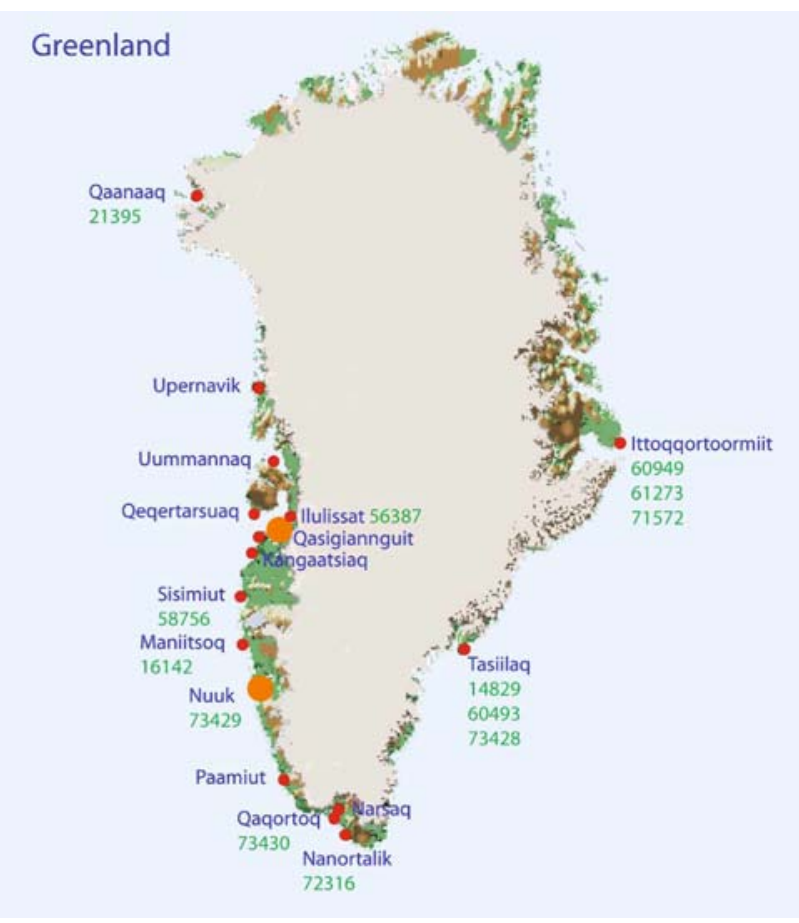

Fig. 5 Geographic localization of identified Greenlandic BRCA1 nt $234 \mathrm{~T}>\mathrm{G}$ mutation carriers. The localization of the 13 mutation positive carriers with breast and/or ovarian cancer was based on the birthplace of the proband. We have moreover indicated where Greenlandic BRCAl nt $234 \mathrm{~T}>\mathrm{G}$ mutation carriers from the population screening were identified (orange). The figure is adapted from www.statgreen.gl/images/glmap.gif

relative small size of the Greenlandic population and potential preventive and therapeutic benefit of identifying gene carriers, population screening could be warranted. In Denmark gene carriers are offered a screening program and treatment as described in national guidelines from the Danish Breast Cancer Group (DBCG), and these could also apply to the Inuit population. The total number of breastand ovarian cancer cases is 68 and 16 per year, respectively [39]. Assuming a penetrance of $80 \%$ and $50 \%$ for breast and ovarian cancer, respectively [1], we estimate, that the BRCAl nt $234 \mathrm{~T}>\mathrm{G}$ founder mutation accounts for about $5 \%$ of all breast cancers and up to $13 \%$ of all ovarian cancers among the Greenlandic Inuit population.

Acknowledgements Nina Ilsøe, Bettina M. Andersen, Karina Nørgaard and Lis Krüger are acknowledged for excellent technical assistance. This study was supported by the Neye Foundation.

\section{References}

1. Thompson D, Easton D (2004) The genetic epidemiology of breast cancer genes. J Mammary Gland Biol Neoplasia 9(3):221236. doi:10.1023/B:JOMG.0000048770.90334.3b

2. Jasin M (2002) Homologous repair of DNA damage and tumorigenesis: the BRCA connection. Oncogene 21(58):8981-8993. doi:10.1038/sj.onc.1206176
3. Venkitaraman AR (2002) Cancer susceptibility and the functions of BRCA1 and BRCA2. Cell 108(2):171-182. doi:10.1016/S00928674(02)00615-3

4. Davies AA, Masson JY, McIlwraith MJ, Stasiak AZ, Stasiak A, Venkitaraman AR et al (2001) Role of BRCA2 in control of the RAD51 recombination and DNA repair protein. Mol Cell 7(2):273-282. doi:10.1016/S1097-2765(01)00175-7

5. Moynahan ME, Pierce AJ, Jasin M (2001) BRCA2 is required for homology-directed repair of chromosomal breaks. Mol Cell 7(2):263-272. doi:10.1016/S1097-2765(01)00174-5

6. Shin S, Verma IM (2003) BRCA2 cooperates with histone acetyltransferases in androgen receptor-mediated transcription. Proc Natl Acad Sci USA 100(12):7201-7206. doi:10.1073/pnas. 1132020100

7. Marmorstein LY, Kinev AV, Chan GK, Bochar DA, Beniya H, Epstein JA et al (2001) A human BRCA2 complex containing a structural DNA binding component influences cell cycle progression. Cell 104(2):247-257. doi:10.1016/S0092-8674(01) 00209-4

8. Bochar DA, Wang L, Beniya H, Kinev A, Xue Y, Lane WS et al (2000) BRCA1 is associated with a human SWI/SNF-related complex: linking chromatin remodeling to breast cancer. Cell 102(2):257-265. doi:10.1016/S0092-8674(00)00030-1

9. Morris JR, Solomon E (2004) BRCA1: BARD1 induces the formation of conjugated ubiquitin structures, dependent on K6 of ubiquitin, in cells during DNA replication and repair. Hum Mol Genet 13(8):807-817. doi:10.1093/hmg/ddh095

10. Brzovic PS, Meza J, King MC, Klevit RE (1998) The cancerpredisposing mutation $\mathrm{C} 61 \mathrm{G}$ disrupts homodimer formation in the NH2-terminal BRCA1 RING finger domain. J Biol Chem 273(14):7795-7799. doi:10.1074/jbc.273.14.7795

11. Glover JN (2006) Insights into the molecular basis of human hereditary breast cancer from studies of the BRCA1 BRCT domain. Fam Cancer 5(1):89-93. doi:10.1007/s10689-005-2579-z

12. Glover JN, Williams RS, Lee MS (2004) Interactions between BRCT repeats and phosphoproteins: tangled up in two. Trends Biochem Sci 29(11):579-585. doi:10.1016/j.tibs.2004.09.010

13. Borden KL, Freemont PS (1996) The RING finger domain: a recent example of a sequence-structure family. Curr Opin Struct Biol 6(3):395-401. doi:10.1016/S0959-440X(96)80060-1

14. Brzovic RE, Meza PS, King JE, Klevit MC (2001) BRCA1 RING domain cancer-predisposing mutations. Structural consequences and effects on protein-protein interactions. J Biol Chem 276(44):41399-41406. doi:10.1074/jbc.M106551200

15. Brzovic PS, Rajagopal P, Hoyt DW, King MC, Klevit RE (2001) Structure of a BRCA1-BARD1 heterodimeric RING-RING complex. Nat Struct Biol 8(10):833-837. doi:10.1038/nsb1001-833

16. Meza JE, Brzovic PS, King MC, Klevit RE (1999) Mapping the functional domains of BRCA1. Interaction of the ring finger domains of BRCA1 and BARD1. J Biol Chem 274(9):56595665. doi:10.1074/jbc.274.9.5659

17. Wu LC, Wang ZW, Tsan JT, Spillman MA, Phung A, Xu XL et al (1996) Identification of a RING protein that can interact in vivo with the BRCA1 gene product. Nat Genet 14(4):430-440. doi:10.1038/ng1296-430

18. Jin $\mathrm{Y}, \mathrm{Xu} \mathrm{XL}$, Yang MC, Wei F, Ayi TC, Bowcock AM et al (1997) Cell cycle-dependent colocalization of BARD1 and BRCA1 proteins in discrete nuclear domains. Proc Natl Acad Sci USA 94(22):12075-12080. doi:10.1073/pnas.94.22.12075

19. Scully R, Chen J, Ochs RL, Keegan K, Hoekstra M, Feunteun J et al (1997) Dynamic changes of BRCA1 subnuclear location and phosphorylation state are initiated by DNA damage. Cell 90(3):425-435. doi:10.1016/S0092-8674(00)80503-6

20. Joukov V, Chen J, Fox EA, Green JB, Livingston DM (2001) Functional communication between endogenous BRCA1 and its partner, BARD1, during Xenopus laevis development. 
Proc Natl Acad Sci USA 98(21):12078-12083. doi:10.1073/pnas. 211427098

21. Chen A, Kleiman FE, Manley JL, Ouchi T, Pan ZQ (2002) Autoubiquitination of the BRCA1*BARD1 RING ubiquitin ligase. J Biol Chem 277(24):22085-22092. doi:10.1074/jbc. M201252200

22. Hashizume R, Fukuda M, Maeda I, Nishikawa H, Oyake D, Yabuki Y et al (2001) The RING heterodimer BRCA1-BARD1 is a ubiquitin ligase inactivated by a breast cancer-derived mutation. J Biol Chem 276(18):14537-14540. doi:10.1074/jbc.C000881200

23. Lorick KL, Jensen JP, Fang S, Ong AM, Hatakeyama S, Weissman AM (1999) RING fingers mediate ubiquitin-conjugating enzyme (E2)-dependent ubiquitination. Proc Natl Acad Sci USA 96(20):11364-11369. doi:10.1073/pnas.96.20.11364

24. Ruffner H, Joazeiro CA, Hemmati D, Hunter T, Verma IM (2001) Cancer-predisposing mutations within the RING domain of BRCA1: loss of ubiquitin protein ligase activity and protection from radiation hypersensitivity. Proc Natl Acad Sci USA 98(9):5134-5139. doi:10.1073/pnas.081068398

25. Kim H, Chen J, Yu X (2007) Ubiquitin-binding protein RAP80 mediates BRCA1-dependent DNA damage response. Science 316(5828):1202-1205. doi:10.1126/science.1139621

26. Liu Z, Wu J, Yu X (2007) CCDC98 targets BRCA1 to DNA damage sites. Nat Struct Mol Biol 14(8):716-720. doi:10.1038/ nsmb1279

27. Sobhian B, Shao G, Lilli DR, Culhane AC, Moreau LA, Xia B et al (2007) RAP80 targets BRCA1 to specific ubiquitin structures at DNA damage sites. Science 316(5828):1198-1202. doi: $10.1126 /$ science. 1139516

28. Wang B, Elledge SJ (2007) Ubc13/Rnf8 ubiquitin ligases control foci formation of the Rap80/Abraxas/Brca1/Brcc36 complex in response to DNA damage. Proc Natl Acad Sci USA 104(52):20759-20763. doi:10.1073/pnas.0710061104

29. Wang B, Matsuoka S, Ballif BA, Zhang D, Smogorzewska A, Gygi SP et al (2007) Abraxas and RAP80 form a BRCA1 protein complex required for the DNA damage response. Science 316(5828):1194-1198. doi:10.1126/science.1139476

30. Eakin CM, Maccoss MJ, Finney GL, Klevit RE (2007) Estrogen receptor alpha is a putative substrate for the BRCA1 ubiquitin ligase. Proc Natl Acad Sci USA 104(14):5794-5799. doi: 10.1073/pnas.0610887104

31. Mallery DL, Vandenberg CJ, Hiom K (2002) Activation of the E3 ligase function of the BRCA1/BARD1 complex by polyubiquitin chains. EMBO J 21(24):6755-6762. doi:10.1093/emboj/cdf691

32. Starita LM, Horwitz AA, Keogh MC, Ishioka C, Parvin JD, Chiba N (2005) BRCA1/BARD1 ubiquitinate phosphorylated RNA polymerase II. J Biol Chem 280(26):24498-24505. doi: 10.1074/jbc.M414020200

33. Starita LM, Machida Y, Sankaran S, Elias JE, Griffin K, Schlegel BP et al (2004) BRCA1-dependent ubiquitination of gammatubulin regulates centrosome number. Mol Cell Biol 24(19):8457-8466. doi:10.1128/MCB.24.19.8457-8466.2004

34. Wu W, Nishikawa H, Hayami R, Sato K, Honda A, Aratani S et al (2007) BRCA1 ubiquitinates RPB8 in response to DNA damage. Cancer Res 67(3):951-958. doi:10.1158/0008-5472.CAN-06-3187

35. Yu X, Fu S, Lai M, Baer R, Chen J (2006) BRCA1 ubiquitinates its phosphorylation-dependent binding partner CtIP. Genes Dev 20(13):1721-1726. doi:10.1101/gad.1431006

36. Morris JR, Pangon L, Boutell C, Katagiri T, Keep NH, Solomon E (2006) Genetic analysis of BRCA1 ubiquitin ligase activity and its relationship to breast cancer susceptibility. Hum Mol Genet 15(4):599-606. doi:10.1093/hmg/ddi476

37. Bjerregaard P, Curtis T, Borch-Johnsen K, Mulvad G, Becker U, Andersen S et al (2003) Inuit health in Greenland: a population survey of life style and disease in Greenland and among Inuit living in Denmark. Int J Circumpolar Health 62(Suppl 1):3-79
38. Knudson AG Jr (1971) Mutation and cancer: statistical study of retinoblastoma. Proc Natl Acad Sci USA 68(4):820-823. doi: 10.1073/pnas.68.4.820

39. Friborg J, Koch A, Wohlfarht J, Storm HH, Melbye M (2003) Cancer in Greenlandic Inuit 1973-1997: a cohort study. Int J Cancer 107(6):1017-1022. doi:10.1002/ijc. 11502

40. Abkevich V, Zharkikh A, Deffenbaugh AM, Frank D, Chen Y, Shattuck D et al (2004) Analysis of missense variation in human BRCA1 in the context of interspecific sequence variation. J Med Genet 41(7):492-507. doi:10.1136/jmg.2003.015867

41. Brzovic PS, Keeffe JR, Nishikawa H, Miyamoto K, Fox D 3rd, Fukuda $\mathrm{M}$ et al (2003) Binding and recognition in the assembly of an active BRCA1/BARD1 ubiquitin-ligase complex. Proc Natl Acad Sci USA 100(10):5646-5651. doi:10.1073/pnas. 0836054100

42. Gayther SA, Warren W, Mazoyer S, Russell PA, Harrington PA, Chiano $\mathrm{M}$ et al (1995) Germline mutations of the BRCA1 gene in breast and ovarian cancer families provide evidence for a genotype-phenotype correlation. Nat Genet 11(4):428-433. doi: $10.1038 / n g 1295-428$

43. Holt JT, Thompson ME, Szabo C, Robinson-Benion C, Arteaga CL, King MC et al (1996) Growth retardation and tumour inhibition by BRCA1. Nat Genet 12(3):298-302. doi:10.1038/ng0396-298

44. Thompson D, Easton D (2002) Variation in BRCA1 cancer risks by mutation position. Cancer Epidemiol Biomarkers Prev 11(4): 329-336

45. Gayther SA, Mangion J, Russell P, Seal S, Barfoot R, Ponder BA et al (1997) Variation of risks of breast and ovarian cancer associated with different germline mutations of the BRCA2 gene. Nat Genet 15(1):103-105. doi:10.1038/ng0197-103

46. Bergman A, Einbeigi Z, Olofsson U, Taib Z, Wallgren A, Karlsson P et al (2001) The western Swedish BRCA1 founder mutation 3171ins5; a $3.7 \mathrm{cM}$ conserved haplotype of today is a reminiscence of a 1500-year-old mutation. Eur J Hum Genet 9(10):787-793. doi:10.1038/sj.ejhg.5200704

47. Dorum A, Hovig E, Trope C, Inganas M, Moller P (1999) Three per cent of Norwegian ovarian cancers are caused by BRCA1 1675delA or 1135insA. Eur J Cancer 35(5):779-781. doi: 10.1016/S0959-8049(99)00050-7

48. Simard J, Tonin P, Durocher F, Morgan K, Rommens J, Gingras $S$ et al (1994) Common origins of BRCA1 mutations in Canadian breast and ovarian cancer families. Nat Genet 8(4):392-398. doi: 10.1038/ng1294-392

49. Thorlacius S, Olafsdottir G, Tryggvadottir L, Neuhausen S, Jonasson JG, Tavtigian SV et al (1996) A single BRCA2 mutation in male and female breast cancer families from Iceland with varied cancer phenotypes. Nat Genet 13(1):117-119. doi: 10.1038/ng0596-117

50. Helgason A, Palsson G, Pedersen HS, Angulalik E, Gunnarsdottir ED, Yngvadottir B et al (2006) mtDNA variation in Inuit populations of Greenland and Canada: migration history and population structure. Am J Phys Anthropol 130(1):123-134. doi: 10.1002/ajpa.20313

51. Thorlacius S, Sigurdsson S, Bjarnadottir H, Olafsdottir G, Jonasson JG, Tryggvadottir L et al (1997) Study of a single BRCA2 mutation with high carrier frequency in a small population. Am J Hum Genet 60(5):1079-1084

52. Roa BB, Boyd AA, Volcik K, Richards CS (1996) Ashkenazi Jewish population frequencies for common mutations in BRCA1 and BRCA2. Nat Genet 14(2):185-187. doi:10.1038/ng1096-185

53. Struewing JP, Abeliovich D, Peretz T, Avishai N, Kaback MM, Collins FS et al (1995) The carrier frequency of the BRCA1 185delAG mutation is approximately 1 percent in Ashkenazi Jewish individuals. Nat Genet 11(2):198-200. doi:10.1038/ng1095-198 